\title{
THE JOB EXCHANGES FOR GRADUATES IN ROMANIA - THE ASSESSMENT OF THE TERRITORIAL DISPARITIES
}

\author{
Irena MOCANU \\ Institute of Geography, Romanian Academy, Romania
}

\begin{abstract}
The job exchanges for graduates represent the major offer-and-demand framework organised by the majority of territorial structures of the National Employment Agency, which have a pyramidal/hierarchic structure. The paper focuses on supply and demand territorial aspects on the labour market for graduates; how employer demand is conveyed to graduates and how well the skills that young people gain are utilized on the job. The present study represents a quantitative assessment of the job supply and demand for graduates and a qualitative territorial assessment of the results recorded by the jobexchange for this category of young labour force. This latter approach is based on a series of 7 indicators, in order to point out the main territorial characteristics of the job exchange for graduates. The general assessment index (calculated like the arithmetical average of the standardized values of the indicators selected) varies between 0 and 0.762 , the agencies for employment being divided in four categories: 1 - "No activity and no results", 2 - "Very low activity and very few results" and "Low activity and very few result", 3 - "Low activity and few results" and 4 - "Moderate activity and good results".
\end{abstract}

Key Words: job exchanges for graduates, supply and demand territorial aspects, Romania.

\section{Introduction}

The analysis of the aspects linked with de job exchanges for graduates, including the territorial disparities of the job supply and demand, requires a theoretical approach of various issues, such as: the particular nature of "goods" that has the work/labour (McConnell, Brue, MacPherson 2003), the role of the political, economic, institutional and educational systems for the succes of the active labour market policy (De Günter, O'Reilly, Schöman 1996), the complex relationships (quantitative, structural, geographical position) between the job supply and demand, between the different types of organization of labour market (Holm, Lorenz, Lundvall, Valeyre 2008), the importance od employability, with many economic, social and psychological benefits attached to it (Cherry, Rodgers 2000, McConnell, Brue, MacPherson 2003), etc.

The job exchanges for graduates represent a way for the increasing the employability, a concept defined as the relative capacity of an individual to achieve meaningful employment, given the interaction between personal characteristics and the labour market, because this type of job-exchange intends to built successful model for the transition of the graduates into employment, which implies bringing together, in a coherent framework, all of the elements affecting employability: education, training, counselling, prior learning and skill assessment, labour market information, hiring and separation practice, work organization, equity, human resources planning and employer-employee relations. In the exchange process between supply 
and demand, it is critical to examine these components of the labour market and the characteristics of the matching process itself because the creation of jobs in a modern society are almost independent processes (Ranney, Betancur 1992, Kalleberg, Sørensen 1979). Job exchange aims to facilitate the job/worker mismatches, through which are lead to reduced input flows in unemployment, negative job attitude, and low job satisfaction. Potential discrepancies exist in this exchange. The first is a discrepancy between the skills possessed and the skills required, the second failure is the immobility of workers among occupations and places and the third, there are problems in information flows and possibly even in comprehending that information (De Ron, Deller, Marcouiller, 2004); information on the location of jobs and the skills, required must be widely available to members of the labour force (Ranncy, Betancur 1992, Schaeffer 1985, 1987). It is necessary to consider not only factors that affect the supply side of the labour market (such as access to education and training opportunities), but also the demand side (what employers have to offer) and the interplay between supply and demand that is mediated in part by the exchange of labour market information (Brisbois, Orton, Saunders 2008). The results of a job-exchange for graduates should be a measure of the effectiveness of the national, county and local agencies for employment, in fact a measures of the instittional effectiveness in labour marcket field. Political economy variables, such as left party power (Korpi 1983, 1991, Shalev 1983), unemployment rates, labour force participation rates and other variables may have a strong impact on the effectiveness of active labour market policy. In same time, those variables should be controlled to measure the impact of institutional context (Janoski 1990, 1994).

Recent work on systems of innovation (Amable 2003, Hall, Soskice 2001, Lorenz, Lundvall 2006, Whitley 2006, quoted by Holm, J., Lorenz, Lundvall, Valeyre 2008) has argued that there are systematic relations between the structure of labour markets and systems of social protection on the one hand, and the dynamics of knowledge accumulation and learning at the work place on the other. Active labour market policies, including expenditures on continuous vocational education and other forms of lifelong- learning, contribute to the flexibility of labour markets by supporting the continuous reconfiguration of the workforce's skills and competences (Holm, Lorenz, Lundvall, Valeyre 2008). Based on the analyses and set of variables used in the research (European Working Conditions Survey - EWCS, 2005, Eurostat's Labour Force Survey, from Romans, Hardarson 2007), four main types of work organization were identified: the discretionary learning ${ }^{1)}$, lean production ${ }^{2)}$, Taylorist ${ }^{3)}$ and traditional or simple structure ${ }^{4)}$ forms of work organization (Working conditions in the European Union: Work organization, 2008). The study shows that the lean forms are most present in the new EU member nations (Latvia, Lithuania, Poland and Romania), in the UK and Portugal amongst the EU-15; Taylorist forms are relatively developed in all of the southern nations amongst the EU-15 and in a number of the new member nations including the Czech Republic, Cyprus, Hungary, Bulgaria and Romania (Fig. 1).

1)The discretionary learning is characterized by high levels of autonomy at work, learning and problem solving, task complexity, self-assessment of quality of work and, to a lesser extent, autonomous teamwork.

2) Lean production is defined by a higher level of teamwork and job rotation, self-assessment of quality of work and quality norms, and the various factors constraining work pace.

3) Taylorist corresponds to low autonomy at work, particularly in methods of work, few learning dynamics, little complexity and an overrepresentation of the variables measuring constraints on the pace of work, repetitiveness and monotony of tasks, and quality norms.

4) Traditional or simple structure all of the variables of work organization are underrepresented and methods are largely informal and non-codified (Source: Working conditions in the European Union: Work organization, 2008). 


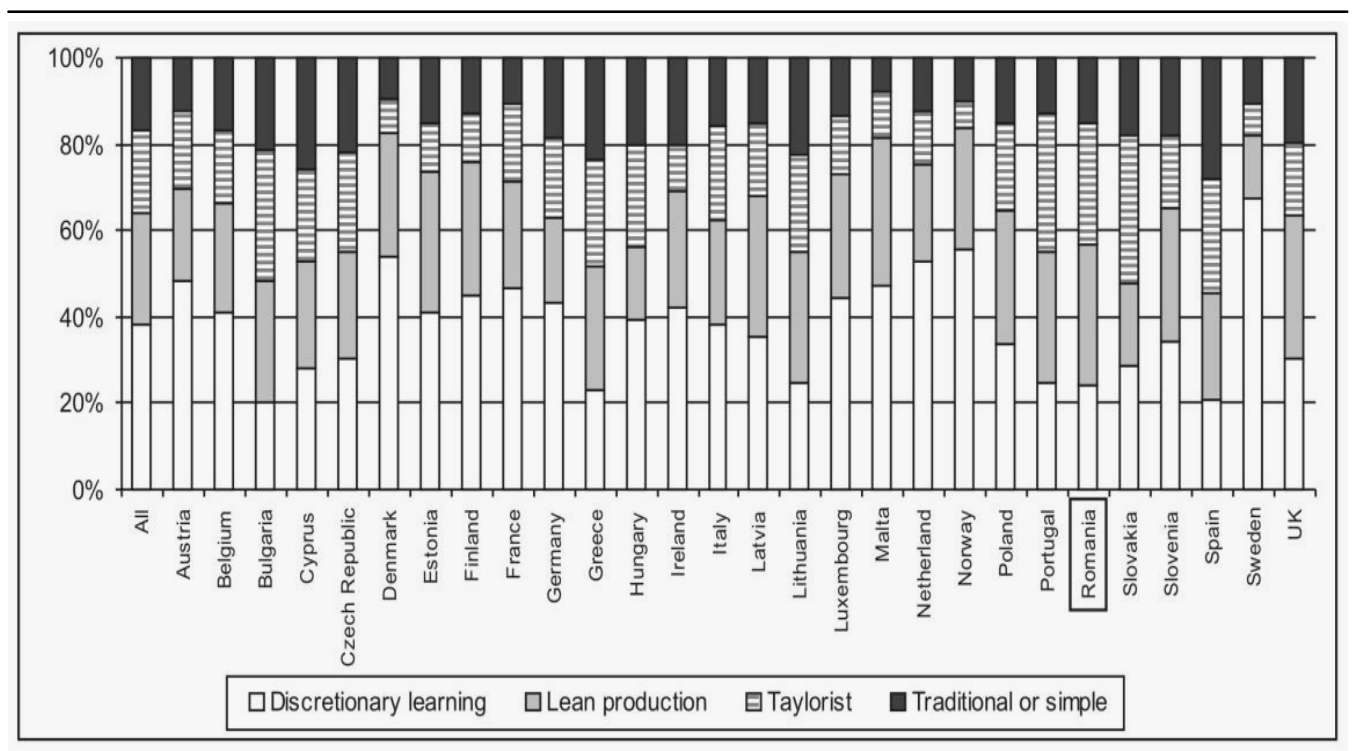

Fig. 1 - Distinctions between countries in forms of work organisation (weighted percent of employees by organisational class) - 2005

(Source: processed information from Holm, J., Lorenz, E., Lundvall, B., Valeyre, A. (2008), Work Organisation and Systems of Labour Market Regulation in Europe, http://vbn.aau.dk/files/16278109/ HolmLorenzLundvallValeyre_EAEPE08.pdf)

The aim of the different categories of job exchanges (general job exchanges, for youth, for graduates, for Rroma, for persons with disabilities etc.) is to supply vacancies work places and to assure the employment. In same time, the job exchanges represent a type of preventive measure applied on the labour market, the target being obtaining the benefits both, the employer and the job seekers. The current economic-financial crisis has sharply reduced the chances for graduates to find a job and, at the same time, unemployment among this category rose in entire country. Therefore, job-exchanges for graduates represent an important labour supply-and-demand framework. The job-exchanges for graduates are organised in September, by all 41 county agencies (+ Agency for Employment of Bucharest Municipality) and by the majority of local agencies for employment and some of the profile working points. During the 2008, 2009 and 2010, the host agencies decreased number, the job supply for graduates and the potential employers were in decline (by $47.6 \%$ during the current crisis and by $32.9 \%$, respectively); at the same interval, the job demand increased by $8.7 \%$, and the job demand of the graduates was higher by $8.1 \%$ in 2010 , compared with 2008 (Fig. 2).

In September 2010, job exchanges for graduates were being held in 86 localities, but only a number of 80 agencies out of the 86 studied had discharged a concrete activity and registered positive results, the others did not benefit by the participation of any economic agent, although about 25-30 had been contacted. Most of these job exchanges were organised by county and local Agencies for Employment (78.9\%) rather than by profile working points (Fig. 3). 


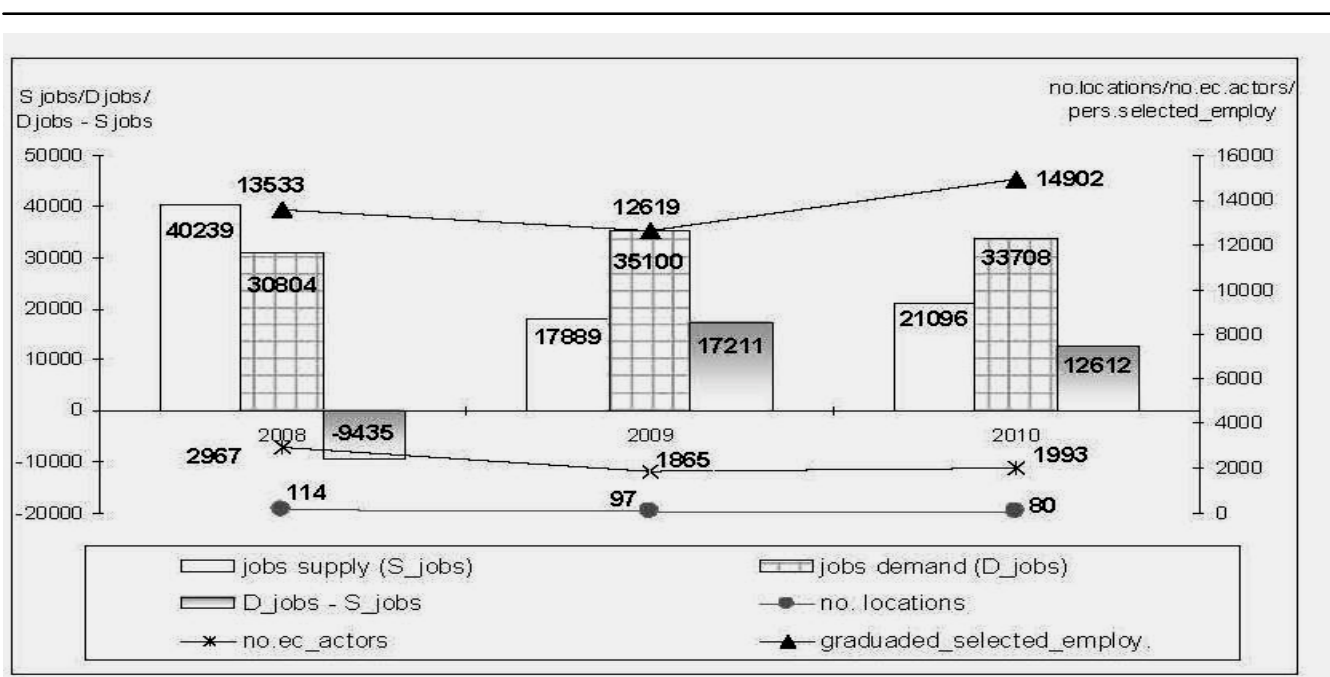

Fig. 2 - General features of the job exchanges for graduates (2008, 2009 and 2010) (Source: information processed from National Agency for Employment )

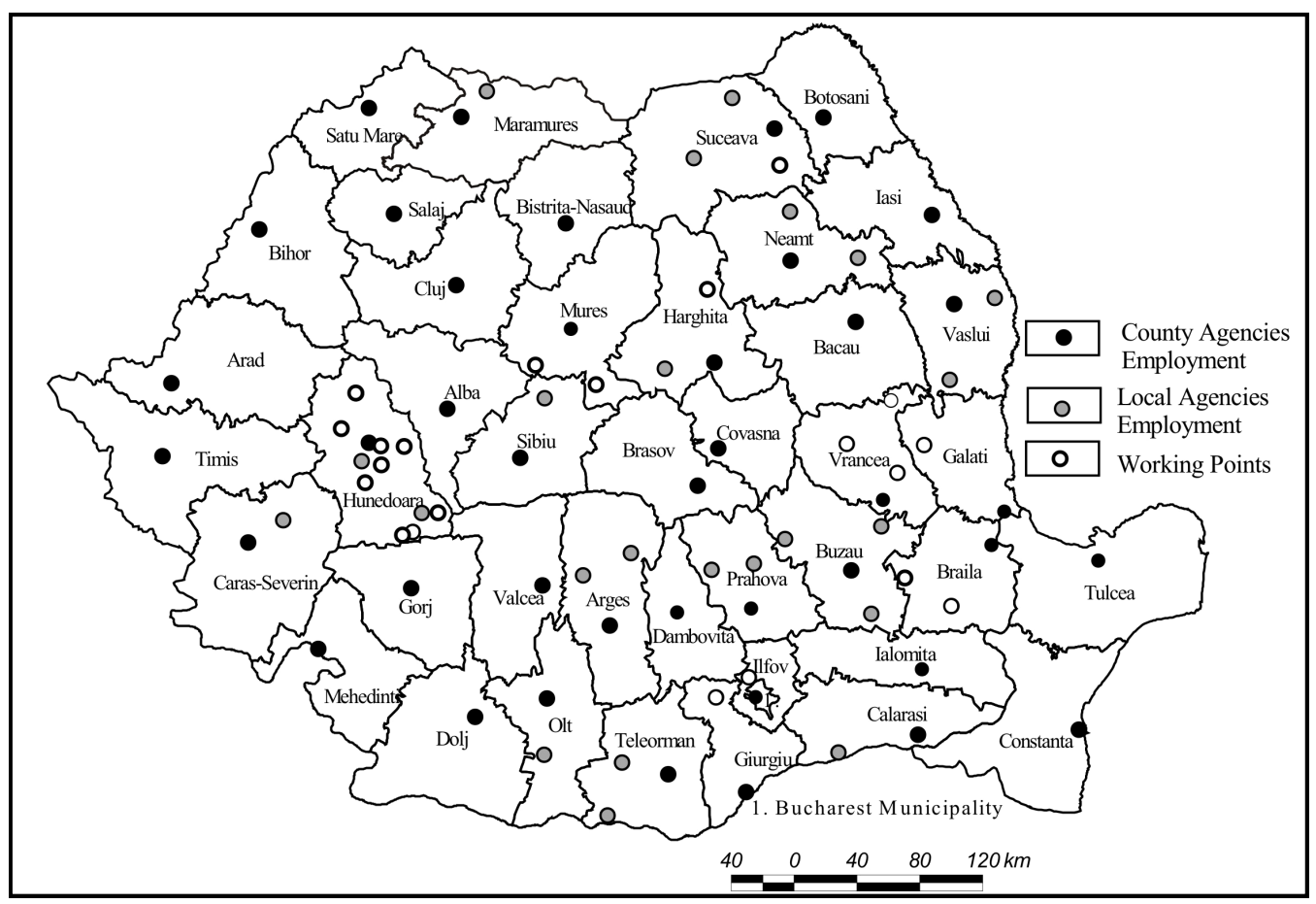

Fig. 3 - The job exchanges for graduates on the map (2010)

(Source: mapped information from National Agency for Employment ) 


\section{Materials and Methods}

The data-base used is based on the reports on job-exchanges for graduates, published on-line by the National Agency for Employment, under the title Sinteza datelor privind rezultatele obtinute la Bursa locurilor de munca pentru absolvenți din data de 24.09.2010 - evaluare la o lună - Summary data on the results of the Job exchanges for graduates dated September, 24, 2010 - one month evaluation, (www.anofm.ro). The job exchanges statistical-data are presented in terms of absolute values and the multitude of the type of information offers the possibility to realise some structural/qualitative assessments of the job supply and demand and of the results of the job-exchange for graduates at NUTS III and NUTS V levels.

The present study represents a quantitative assessment of the job supply and demand for graduates and a qualitative territorial assessment of the results recorded by the job exchanges for this category of young labour force. This latter approach is based on a series of 7 indicators, in order to point out the main territorial characteristics of the job exchange for graduates: the percentage of economic agents participant per total contacted economic agents; the job supply; the job demand; the graduates' job demand; the job supply/job demand; the number of total employed under the job-exchange supply; the number of total graduates employed under the job-exchange supply. The general/complex assessment of the job exchange for graduates is calculated like the arithmetical average of the standardized values of the indicators selected.

\section{Results and Discussion}

Job supply depends on the proportion of economic agents per contacted agents who actually participated in the job-exchange set up in each county. Percentages were under 57, highest

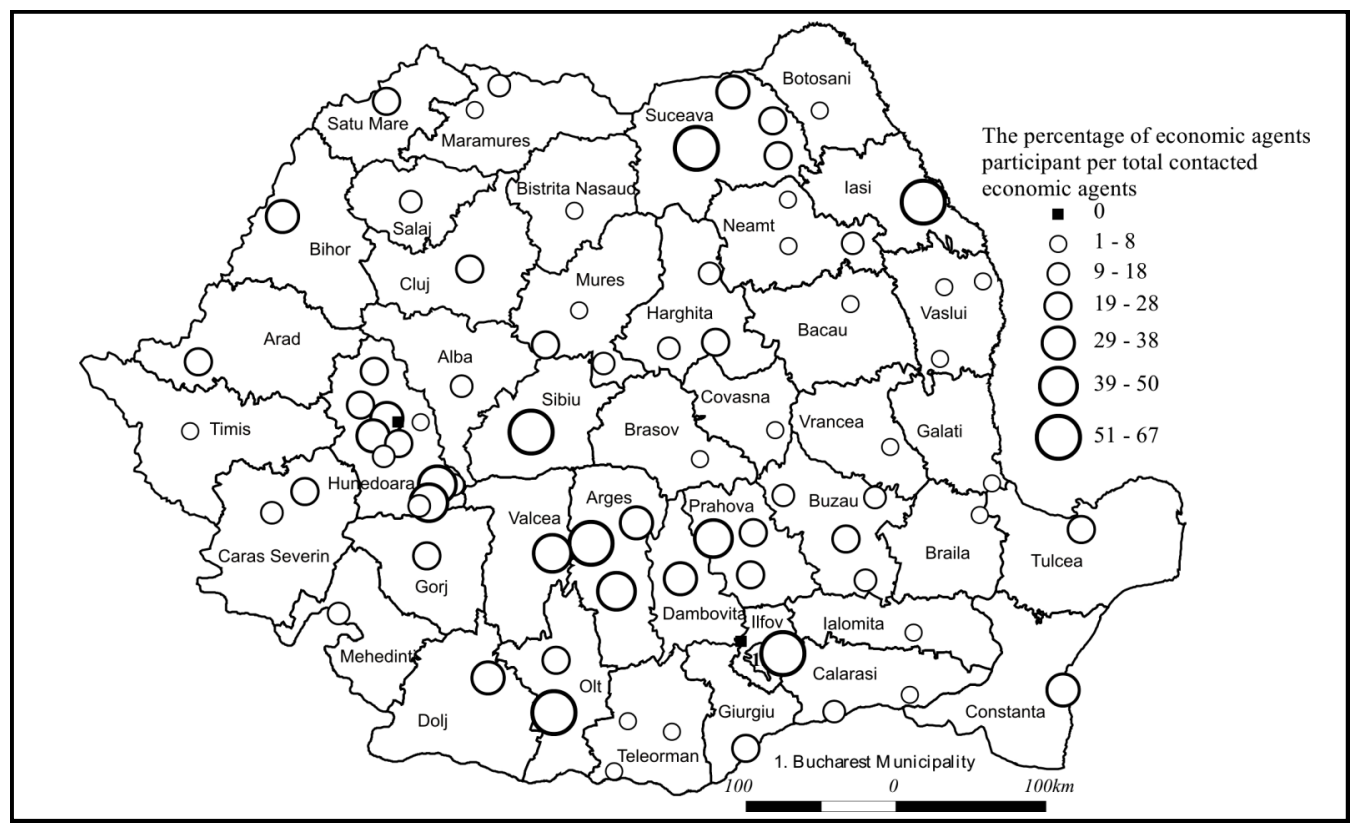

Fig. 4 - The economic agents participant

(Source: mapped information from National Agency for Employment) 
participation (39\%-57\%) registered laşi, Vaslui, Sibiu and Argeş; medium participation registered Suceava and Bihor, a group of counties from the south-west of Romania (Gorj, Dolj, Olt), Dâmbovița and Constanța. In the other 31 counties few and very few contacts attended, so that the supply itself was reduced (under $10 \%$ and down to a minimum of $0.4 \%$ in Ilfov County) (Fig. 4).

The territorial distribution of the job supply shows that county agencies headed the table (Bucureşti, Timişoara, Oradea, laşi, Cluj-Napoca, Braşov etc.), second in line coming the local agencies, some county agencies (Arad, Satu Mare, Drobeta-Turnu-Severin, Suceava, Galați etc.), local agencies and working points fell to the bottom of the hierarchy (Fig. 5).

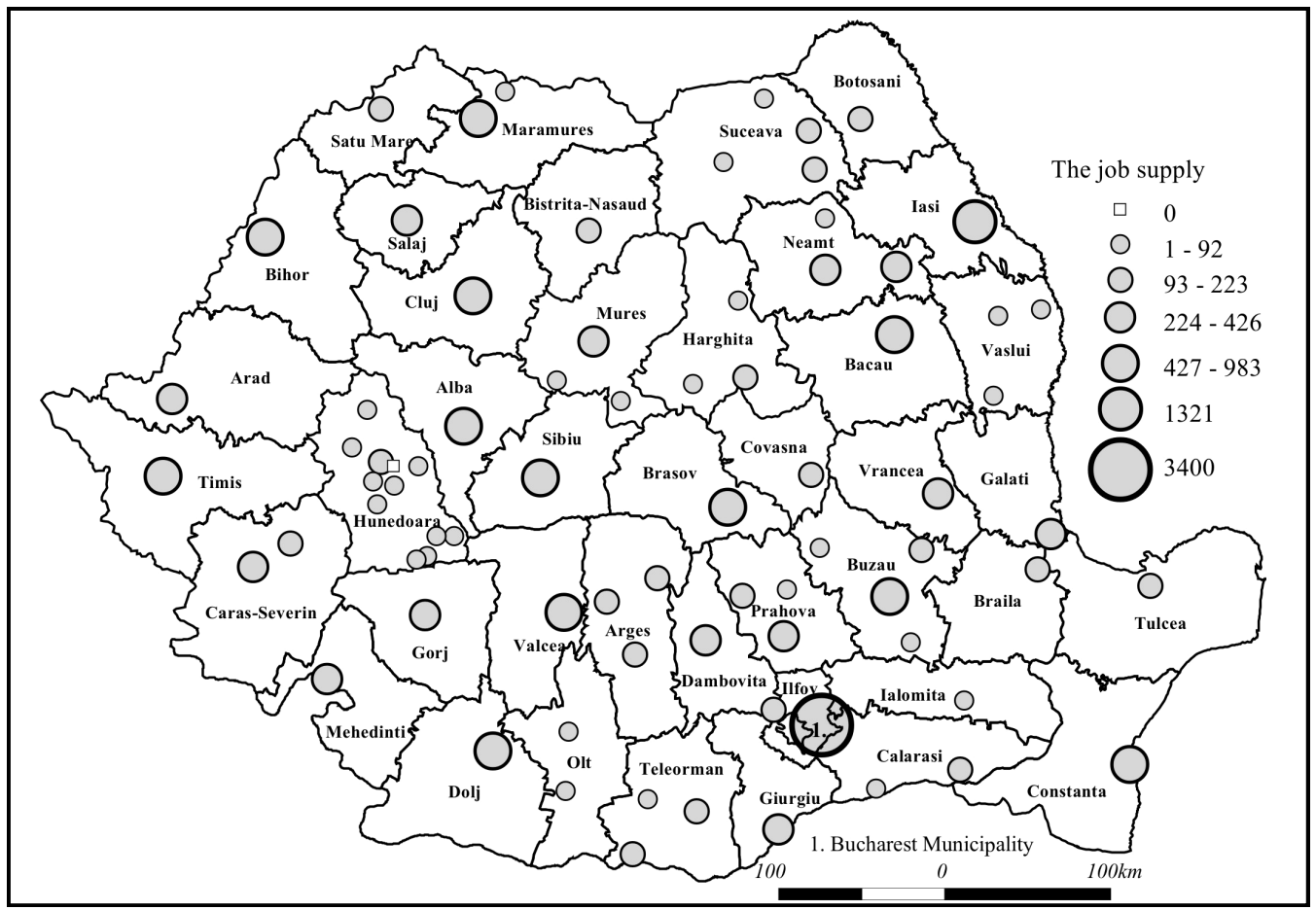

Fig. 5 - The job supply

(Source: mapped information from National Agency for Employment )

Job demand. As far as organising agencies are concerned, demand depended largely on the territorial position of the respective agency within the National Agency for Employment system. More than 1,000 applications registered each of the following county-seat agencies: laşi, Timişoara, Cluj-Napoca, Oradea, Râmnicu Vâlcea, Braşov, and the city of Bucharest; between 999 and 250 had the vast majority of the other county-seat agencies, with the exception of Deva and Călăraşi (only 51 and 76 applications, respectively); local agencies and working points received 4,441 applications (Fig. 6). 


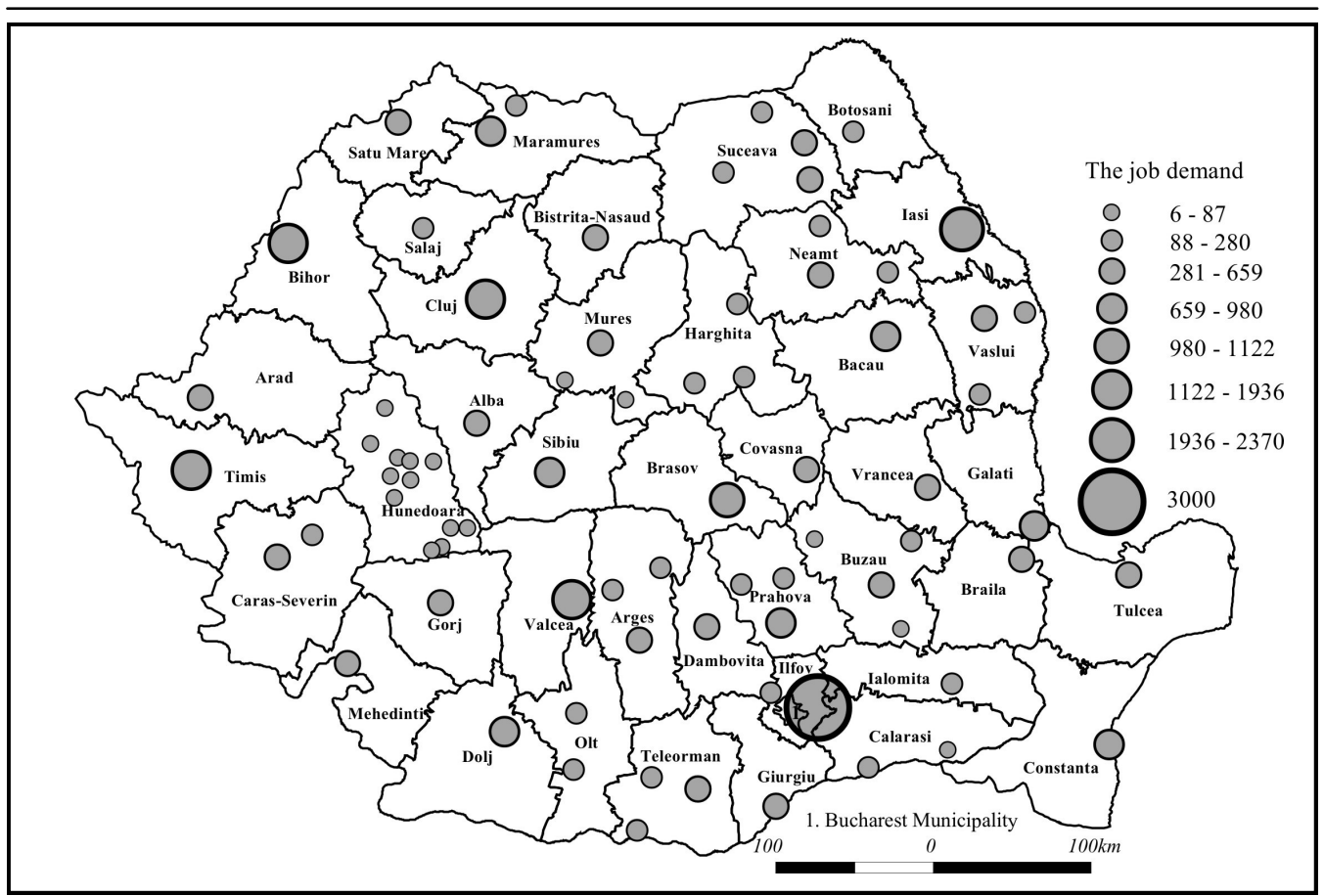

Fig. 6 - The job demand

(Source: mapped information from National Agency for Employment)

In 2010 , there is by $3.9 \%$ fewer employment seekers than in the previous year, more applications having been registered in Romania's counties situated in the north-east and north (laşi and Suceava), east (Vaslui and Bacău), west and centre (Timiş, Bihor, Cluj and Braşov), south and south-east (Bucharest, Prahova and Vâlcea, Dolj, Argeş and Teleorman).

In the major university centres, the proportion of graduates who applied for a job was of $77.2 \%$. Numerical disparities in the territory are due on the one hand, to the negative effects of the current crisis on the regional and local economies, and on the others, to the large number of students enrolled in the higher education system in particular. The flows of graduates originate from Bucharest and the other three big university centres (Cluj-Napoca, laşi and Timişoara), as well as from regional centres (Craiova, Constanța, Oradea, Braşov, Sibiu and Galați) set up within distinct historical regions, or in areas of regional interferences (Research aimed at the involvement of Romanian universities in urban restructuring and regional development, http:// www.cicadit.ro/ro/projects_n2_2_1.html). In some areas at least, the latter category of graduates outnumbered market demand (Fig. 7).

The relationship between job supply and job demand. Results. In the majority of counties and more especially in Timiş, Bihor, Cluj, laşi and Prahova, the supply was by far lower than the demand, the same situation in other counties situated in the north and east (Suceava, Vaslui and Galați), south and south-west of Romania (Teleorman, Vâlcea and Dolj). In nine agencies for employment, situated in west and south parts of the country, the job supply topped 
demand, the highest two values being registered in Hunedoara (3.7) and Deva (2.6). Alba-lulia, Călăraşi, Zalău and Buftea towns had a balanced relationships between job supply and job

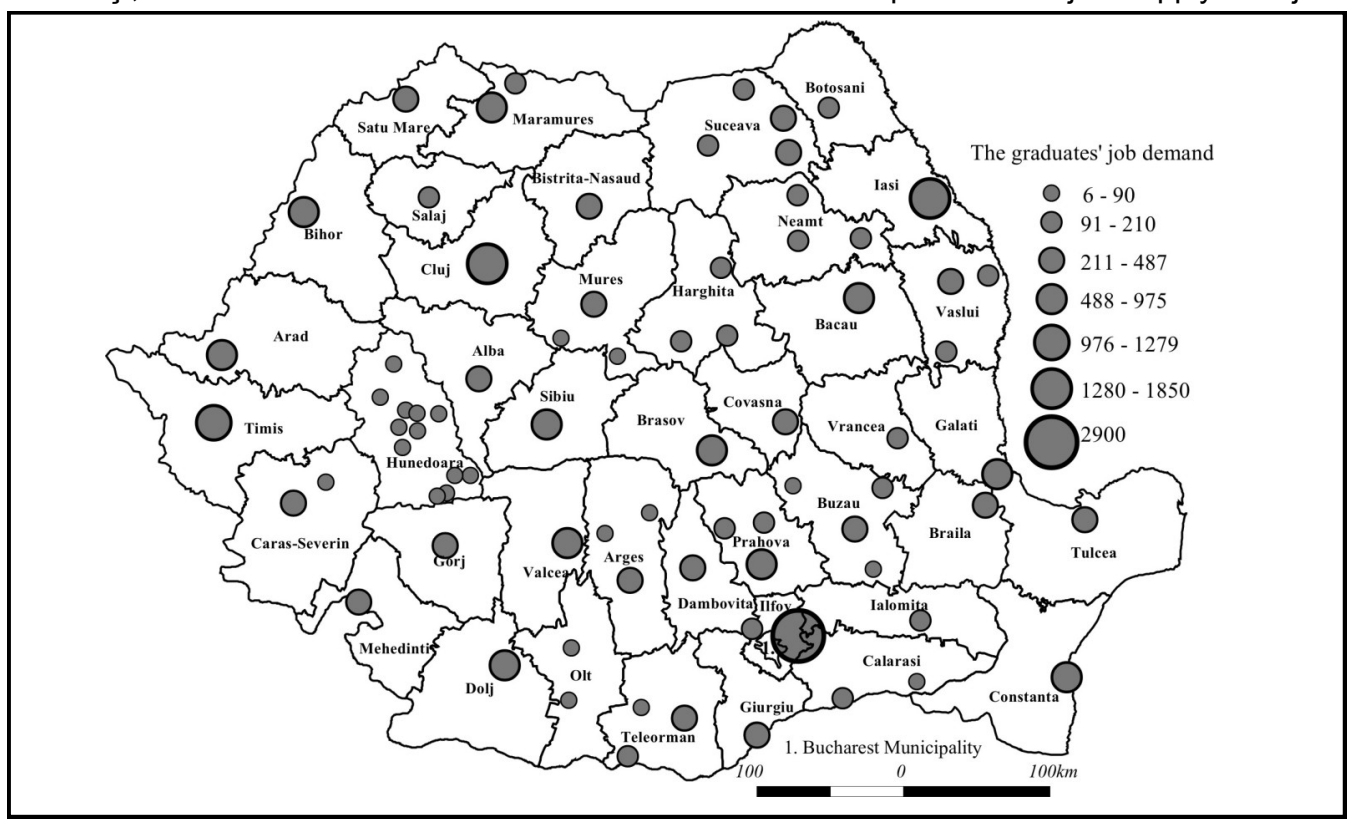

Fig. 7 - The graduates' job demand

(Source: mapped information from National Agency for Employment )

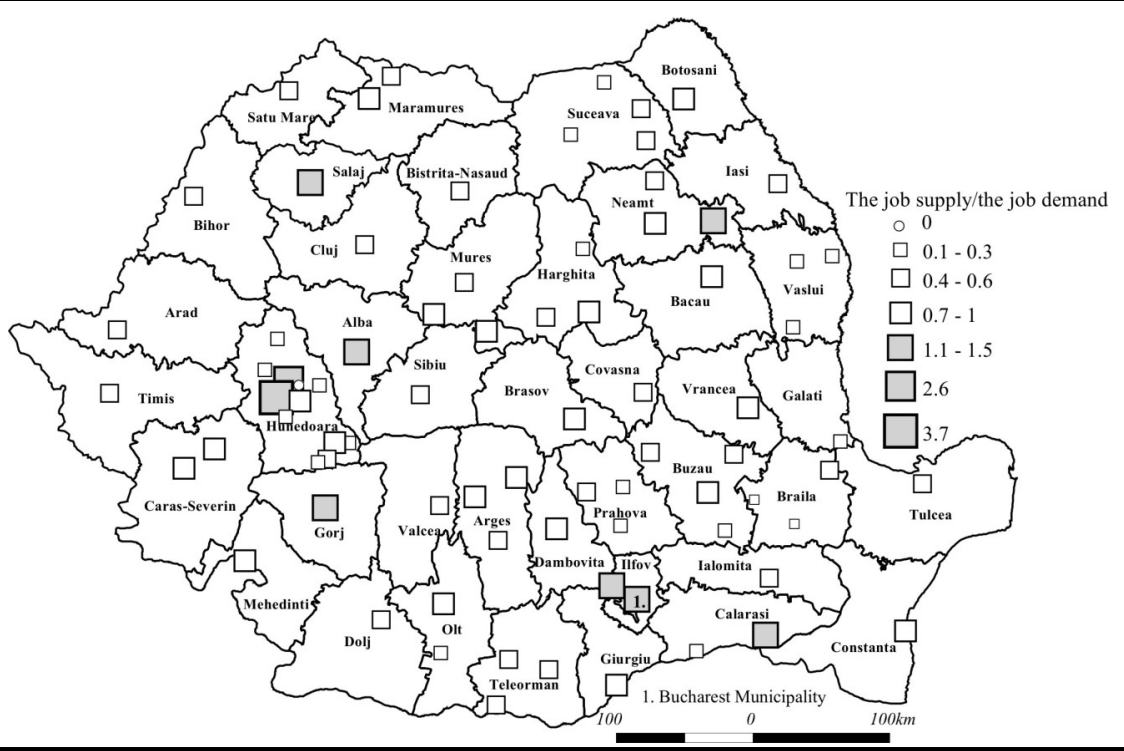

Fig. 8 - The job supply/job demand

(Source: mapped information from National Agency for Employment) 
demand (1.5 - 1.2) and Bucharest, Roman and Târgu Jiu had the same value, respectively, 1.1 (Fig. 8).

Concerning the number of total employed under the job exchange supply, in 2010, the situation appeared to be far better than in 2009 (1.8\% of employed persons per total participants), since $5.1 \%$ of the job-seekers could be employed through all types of job-exchange profiles (job-exchanges were instituted under Law 76, art. 59 and Law 116, art. 5, http://www.anofm.ro/ medierea-muncii-actualizat-la-28-03-2011). However, in the case of job-exchange for graduates, the year 2010 was among the poorest compared to the other types of exchange) (Table 1).

Table 1

The results of the different types of job-exchange organised by the National Agency for Employment in 2010

\begin{tabular}{|l|c|}
\hline \multicolumn{1}{|c|}{ Type of job-exchange } & \% of employed persons per total participants \\
\hline General job-exchange & $17 \%$ \\
\hline Job-exchanges for different jobs and economic branches & $17 \%$ \\
\hline $\begin{array}{l}\text { Job-exchanges for different target-groups and less- } \\
\text { favorised persons }\end{array}$ & $12.9 \%$ \\
\hline Job exchanges for graduates & $\mathbf{1 2 . 1} \%$ \\
\hline
\end{tabular}

Source: statistic information processing from Sinteză privind stadiul realizării Programului de ocupare a forței de muncă al ANOFM, pentru anul 2010.

The number of total employed under the job-exchange supply was 3,847 persons (only $11.4 \%$ per total job demand) and $41.3 \%$ from this total was concentrated in five important towns (Bucharest City, Timişoara, Constanța, Craiova and laşi). Two territorial agencies registered none persons employed (Buftea and Bârlad, each of them with significant job-demand: 170 applicants and, respectively, 275 applicants) and 26 county agencies, local agencies and working points had poor results: the number of employed persons was under 10 persons (Fig. 9). In those cases, the share of employed persons per total job-demand represents a low values: $3.03 \%$ (3,097 job demands and 94 persons employed). Those weak results were specific for some areas with important and long-term problems concerning employment and unemployment, for example, the mining towns and steel-towns from Hunedoara and CaraşSeverin counties. In those towns, the total job demand was 757 applicants and the percentage of employed persons was 3.30\%, the most significant discrepancy being registered in Reşița town, where the job demand was 528 applicants and the number of persons employed was 5 $0.002 \%)$.

For having a better picture of the employment of graduates, the analysis of the territorial distribution of the graduates employed per applicant graduates is very useful. So, the employment of graduates varied widely $(0 \%-78 \%)$ compared to the national mean $(12.1 \%)$; only 27 job-exchange organising agencies held a better record (Piatra Neamț $-78 \%$, Nehoiu $63 \%$, Hațeg - 53\%, Târgu Jiu - 49\%, Bucharest Municipality - 20\%, Timişoara - 19\% etc.), 49 units standing below average, among which some agencies located in major university centres, e.g. Cluj Napoca - 3\%, laşi $-10 \%$.

Despite this situation, in terms of absolute values of the graduates employed under the job exchange supply, outstanding employment results had the county agencies located in big 
university centres, such as Bucharest (572 graduates), Constanța (287 graduates), Timişoara (238 graduates), Craiova (216 graduates) and laşi (184 graduates). None of the 150 job

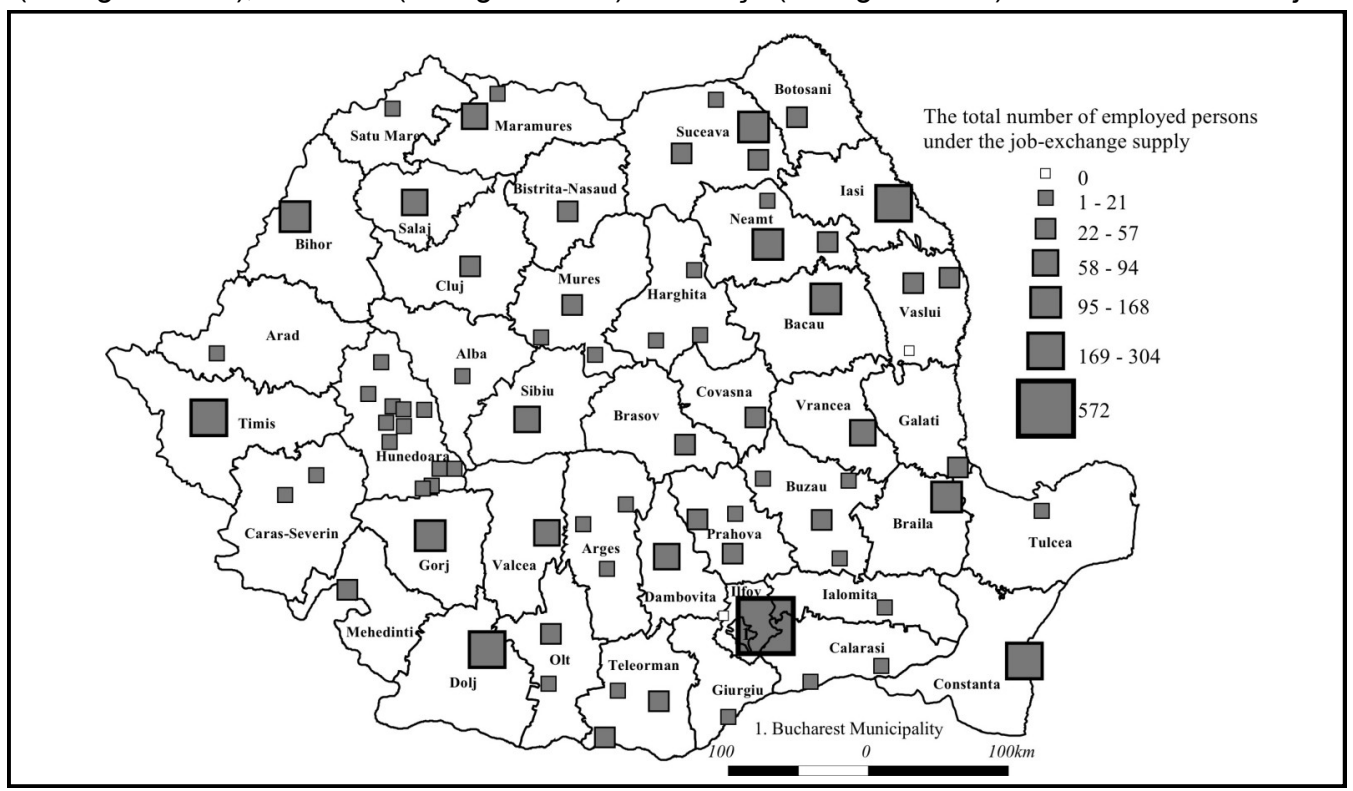

Fig. 9 - The total number of employed persons under the job exchange supply (Source: mapped information from National Agency for Employment )

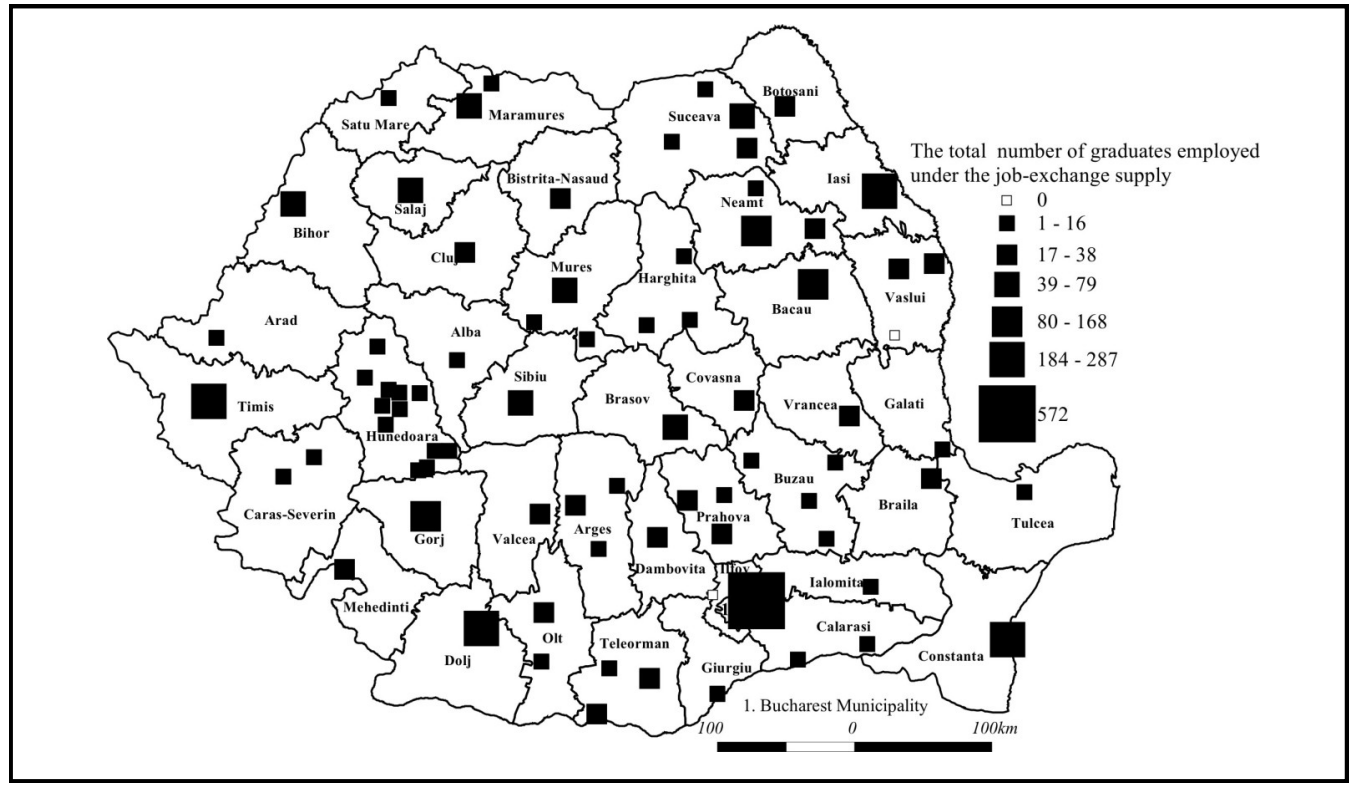

Fig. 10 - The number of total graduates employed under the job exchange supply

(Source: mapped information from National Agency for Employment) 
seekers from Buftea (llfov County) and 100 from Bârlad (Vaslui County) got a work-place through the respective agencies (Fig. 10).

\section{Conclusions}

The general assessment of the job exchange for graduates is calculated like the arithmetical average of the standardized values of the seven indicators selected. The main ideas resulted from the qualitative territorial assessment of the results recorded by this type of job-exchange are the followings:

- two agencies (Insurătei and Făurei, Brăila County) represent the category „No activity and no results", because these did not achieve tangible results, despite the potential economic agents suppliers of jobs and job demand, initially contacted and registered;

- the agencies from the categories "Very low activity and very few results" and "Low activity and very few result" represent the majority $-83.7 \%$. The low efficiency of their activity is motivated by the very low levels of the standardized values of the following secondary indicators: the job supply (0.001, Lupeni, Hunedoara County), the graduates' job demand (0.002, Simeria, Hunedoara County), the number of total employed under the job-exchange supply and the number of total graduates employed under the job-exchange supply (for both indicators - 0.002 , Ilia, Hunedoara County). Basically, the overwhelming majority of agencies in these two categories are organised job exchanges for graduates because it was one of their duties under the law for the organisation of county and local agencies for employment, the total number of the persons employed being only 351 (of which 297 graduates), ie $9.1 \%$ of total employed persons after the performance of job exchange;

- 8 county agencies represent the category "Low activity and few results" because of the average and high levels of the standardized values of the secondary indicators concerning the percentage of economic agents participant per total contacted economic agents (Sibiu -0.853 , laşi - 0.790, Râmnicu Vâlcea - 0.682 şi Craiova - 0.564), the job demand (laşi -0.790 , Timişoara - 0.645, Cluj-Napoca - 0.600 şi Oradea - 0.540) and the graduates' job demand (laşi - 0.683). In these eight agencies were employed 3,847 persons (34.4\% of total persons employed during this type of job exchange), of which $81.9 \%$ were graduates employed;

- "Moderate activity and good results" is the category represented by one agency, namely Municipal Agency of Bucharest. The percentage of economic agents participant per total contacted economic agents was low but the others standardized values of the secondary indicators were the highest. In this agency, the job supply registered the maximum value but it was overwhelmed by the job demand and the percentage of those employed was only $14.8 \%$ (in absolute values, the number of the persons employed was maximum at national level -572 persons).

At national level, job exchange results were pretty low, only $12.1 \%$ of the applicant graduates got a work-place. This is the result of the educational offer in Romania being far higher than actual market needs (Source: Adaptarea activă a educației universitare la cerințele pieței muncii - Real adjustment of academic education to labour-market demands, 2009). The findings of this project have shown that only one-fifth of the graduates are actually needed in the job-market and that the structure of the educational offer is not adjusted to real needs.

Higher education graduates occupied only 334 jobs as against a six-time higher employment among pre-university leavers. This situation also comes from a deficient interaction between 
the labour-market and the universities supplying potential employees. The authors of the volume Educație de calitate pentru piața muncii - Quality education for the labour-market) (published under the Real adjustment of academic education to labour-market demands project) affirm that: the majority of graduates are dissatisfied with the curriculum preparing them for the job-market, practical training sessions being useless, nor had they got the skills and competences required by a job. The project also highlights significant differences between various study-areas. Best employment chances have the graduates from the departments of Computer and Information Technology and from Communication Sciences (74\% in the former case with only $7 \%$ being jobless in the first post-graduation year; in the latter case the proportion is $62 \%$ and $4 \%$, respectively). Differences in findings a job have the graduates from the Faculty of Law and from Mechanical Engineering (a situation affecting 55\% of them;

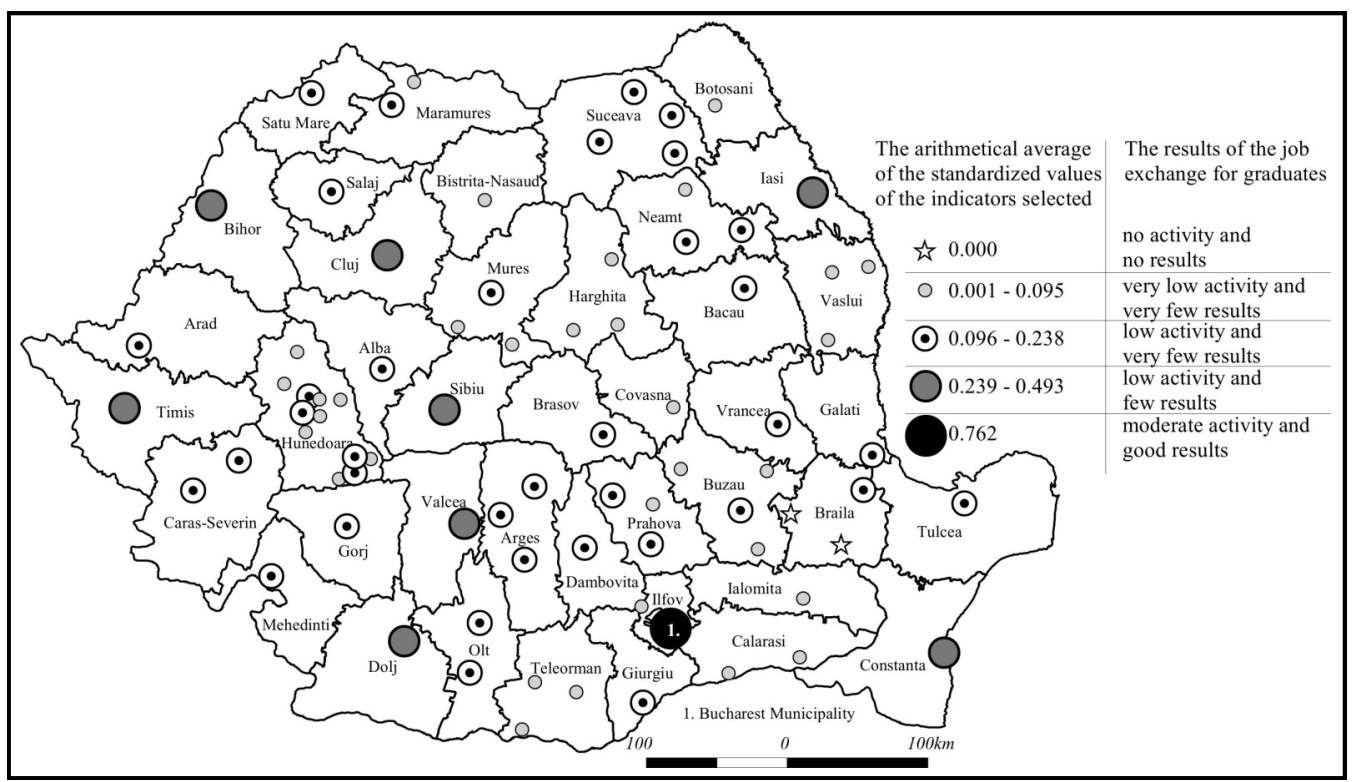

Fig. 11 - The general assessment index of the job-exchange for graduates (Source: mapped information from National Agency for Employment )

unemployment in the first graduation year stands at $11 \%$ and $10 \%$, respectively) (Source: Quality education for the labour-market, 2009).

The main problem is to imply more the universities in the process of attenuating territorial unbalances (lanoş et al. 2010). Involvement potential of a Romanian university in solving local and regional problems, in ensuring the conditions for accelerated development at these levels is extremely varied, taking account of its direct (observed due to its research capacity for a correct individualization of the needs, and for a better solution to cover) and indirect relationships (which implies training of the specialists, local or regional community can having great benefits, using their skills). The partnerships between universities and main actors of the socio-economic, cultural, and politico-administrative life could support universities in constant adaptation of the programs of initial and life-long formation to the specific needs, on the one hand, and could convince local and regional communities to resort, in a usual way, to the expertise, consultancy, and surveys provided by the universities, on the other (lanoş 2008). 
Annex 1

\begin{tabular}{|c|c|c|c|c|c|}
\hline Rank & $\begin{array}{l}\text { Agency/working } \\
\text { point for } \\
\text { employment }\end{array}$ & $\begin{array}{l}\text { The arithmetical } \\
\text { average of the } \\
\text { standardized } \\
\text { values of the } \\
\text { indicators } \\
\text { selected }\end{array}$ & Rank & $\begin{array}{l}\text { Agency/working point } \\
\text { for employment }\end{array}$ & $\begin{array}{l}\text { The arithmetical } \\
\text { average of the } \\
\text { standardized } \\
\text { values of the } \\
\text { indicators selected }\end{array}$ \\
\hline 1 & BUCUREŞTI & 0.762 & 32 & PETROŞANI & 0.138 \\
\hline 2 & IAŞI & 0.493 & 33 & REŞIȚA & 0.132 \\
\hline 3 & TIMIŞOARA & 0.355 & 34 & VULCAN & 0.131 \\
\hline 4 & CONSTANTTA & 0.350 & 35 & CÂMPULUNG & 0.121 \\
\hline 5 & CRAIOVA & 0.308 & 36 & TÂRGU MUREŞ & 0.118 \\
\hline 6 & SIBIU & 0.291 & 37 & SATU MARE & 0.118 \\
\hline 7 & ORADEA & 0.276 & 38 & FOCŞANI & 0.116 \\
\hline 8 & CLUJ-NAPOCA & 0.270 & 39 & TULCEA & 0.114 \\
\hline 9 & RÂMNICU VÂLCEA & 0.259 & 40 & ROMAN & 0.112 \\
\hline 10 & TÂRGU JIU & 0.238 & 41 & FĂLTICENI & 0.109 \\
\hline 11 & HUNEDOARA & 0.217 & 42 & SLATINA & 0.109 \\
\hline 12 & TÂRGOVIŞTE & 0.204 & 43 & $\begin{array}{l}\text { DROBETA-TURNU } \\
\text { SEVERIN }\end{array}$ & 0.105 \\
\hline 13 & BACĂU & 0.200 & 44 & RĂDĂUȚI & 0.104 \\
\hline 14 & BRAŞOV & 0.190 & 45 & BRĂILA & 0.104 \\
\hline 15 & $\begin{array}{l}\text { CÂMPULUNG } \\
\text { MOLDOVENESC }\end{array}$ & 0.185 & 46 & CARANSEBEŞ & 0.102 \\
\hline 16 & DEVA & 0.182 & 47 & MIERCUREA CIUC & 0.095 \\
\hline 17 & CURTEA DE ARGEŞ & 0.176 & 48 & ALEXANDRIA & 0.093 \\
\hline 18 & PLOIEŞTI & 0.174 & 49 & TÂRNĂVENI & 0.090 \\
\hline 19 & BAIA MARE & 0.167 & 50 & BISTRIȚA & 0.089 \\
\hline 20 & PITEŞTI & 0.165 & 51 & BOTOŞANI & 0.087 \\
\hline 21 & SUCEAVA & 0.159 & 52 & SIGHIŞOARA & 0.085 \\
\hline 22 & BUZĂU & 0.156 & 53 & CĂLAN & 0.085 \\
\hline 23 & ZALĂU & 0.156 & 54 & CĂLĂRAŞI & 0.080 \\
\hline 24 & CÂMPINA & 0.153 & 55 & COVASNA & 0.077 \\
\hline 25 & PAŞCANI & 0.153 & 56 & RÂMNICU SĂRAT & 0.076 \\
\hline 26 & ALBA IULIA & 0.150 & 57 & VĂLENII DE MUNTE & 0.071 \\
\hline 27 & GIURGIU & 0.144 & 58 & TURNU MĂGURELE & 0.071 \\
\hline 28 & ARAD & 0.144 & 59 & BUFTEA & 0.070 \\
\hline 29 & PIATRA NEAMT & 0.143 & 60 & SIGHETU MARMAȚIEI & 0.068 \\
\hline 30 & CARACAL & 0.139 & 61 & BRAD & 0.065 \\
\hline 31 & GALAȚI & 0.139 & 62 & VASLUI & 0.060 \\
\hline
\end{tabular}


Irena MOCANU

\begin{tabular}{|c|c|c|c|c|c|}
\hline Rank & $\begin{array}{l}\text { Agency/working point } \\
\text { for employment }\end{array}$ & $\begin{array}{l}\text { The arithmetical } \\
\text { average of the } \\
\text { standardized } \\
\text { values of the } \\
\text { indicators } \\
\text { selected }\end{array}$ & Rank & $\begin{array}{l}\text { Agency/working point } \\
\text { for employment }\end{array}$ & $\begin{array}{l}\text { The arithmetical } \\
\text { average of the } \\
\text { standardized values } \\
\text { of the indicators } \\
\text { selected }\end{array}$ \\
\hline 63 & ILIA & 0.059 & 72 & OLTENIȚA & 0.042 \\
\hline 64 & HUŞI & 0.056 & 73 & PETRILA & 0.040 \\
\hline 65 & GHEORGHENI & 0.055 & 74 & ROŞIORI DE VEDE & 0.037 \\
\hline 66 & ODORHEIU SECUIESC & 0.055 & 75 & POGOANELE & 0.032 \\
\hline 67 & HAȚEG & 0.051 & 76 & BÂRLAD & 0.031 \\
\hline 68 & TÂRGU NEAMT & 0.050 & 77 & ORĂŞTIE & 0.020 \\
\hline 69 & NEHOIU & 0.048 & 78 & SIMERIA & 0.001 \\
\hline 70 & SLOBOZIA & 0.046 & 79 & FĂUREI & 0 \\
\hline 71 & LUPENI & 0.044 & 80 & ÎNSURĂȚEI & 0 \\
\hline
\end{tabular}

\section{References}

AMABLE, B. (2003), The Diversity of Modern Capitalism, Oxford University Press, Oxford.

BRISBOIS, R., ORTON, L., SAUNDERS, R. (2008), Connecting Supply and Demand in Canda's Youth Labour Market, Pathways to the Labour Market Series, no. 8, pp. 1-53, Canadian Policy Research Networks.

CHERRY, R., RODGERS, W. (2000), Prosperity for All? The Economic Boom and African Americans. New York: Russell Sage Foundation.

DE GÜNTER, S., O'REILLY, JAQUELINE, SCHÖMAN, K. (1996), Explaining State Intervention to Prevent Unemployment: The Impact of Institutions on Active Labour Market Policy Expenditures in 18 Countires, in International handbookof labour market policy and evaluation, Edward Elgar Publishing Limited, Cheltenham.

DE RON, S., DELLER, S., MARCOUILLER, D. (2004), Community economics: linking theory and practice, Blackwell Publishing.

Oxford.

HALL, P., SOSKICE, D. (2001), Varieties of Capitalism, Oxford University Press,

HOLM, J., LORENZ, E., LUNDVALL, B., VALEYRE, A. (2008), Work Organisation and Systems of Labour Market Regulation in Europe, http://vbn.aau.dk/files/16278109/ HolmLorenzLundvallValeyre_EAEPE08.pdf.

IANOŞ, I. (2008), The role of the Romanian university in local and regional development, Geographica Timisiensis, vol. 17, nr. 1-2, pp. 17-31.

IANOŞ, I. (coord.), (2010), Territorial Insertion of the Universities from Romania, University Publishing House, Bucharest.

JANOSKI, T. (1990), The Political Economy of Unemployment, Berkely, University of California Press.

JANOSKI, T. (1994), Direct State Intervention in the Labour Market, in The Comparartive Political Economy of the Welfare State, T. Janoski, A. Hicks, Cambridge University Press. 
KALLEBERG, A., SøRENSEN, A. (1979), Sociology of Labor Markets, in Annual Review of Sociology, 5, pp. 351-379.

KATZSTEIN, P. (1984), Corporatism and Change, Ithaca, Cornell University Press, New York. New York.

KATZSTEIN, P. (1985), Small States in World Markets, Ithaca, Cornell University Press,

KORPI, W. (1983), The Democratic Class Struggle, Routledge \& Kegan Paul, London.

KORPI, W. (1991), Political and Economic Explanaitations for Unemployment: A Crossnational and Long-term Analisys, in British Journal of Political Science, 21 (3), pp. 315-348.

LORENZ, E., LUNDVALL, B., A. (2006), How Europe's economies learn, Oxford University Press, Oxford.

MCCONNELL, C., BRUE, S., MACPHERSON, D. (2003), Contemporary Labor Economics, sixth edition, Irwin McGraw-Hill Companies, New York.

RANNCY, D., BETANCUR, J. (1992), Labor Force-Based Development: An Approach to Urban Employment Problems, in Economic Development, Quarterly. 6, 3, pp. 286-296.

ROMANS, F., HARDARSON, O. S. (2007), Eurostat Data in Focus: Labour Market

Latest Trends 2nd quarter 2006 data, Population and social condition no. 1/2007.

SCHAEFFER, P. (1985), Human Capital Accumulation and Job Mobility, in Journal of Regional Science 25(1), pp. 103-114.

SCHAEFFER, P. (1987), A Dynamical Model of Labor Market Change in International Labor Migration When Demand for Labor is Exogenous, in Environment and Planning A 19(8), pp. 1051-1057.

SHALEV, M. (1983), The Social Democratic Model and Beyond, in Comparartive Social Research, 6, pp. 315-351.

SKOCPOL, T., ORLOFF, A. (1986), Explaining the Origins of Welfare States, in Approaches to Social Theory, S. Lindenberg, J. Coleman, S. Nowak, p. 229-254, Russell Sage Foundation, New York.

WHITLEY, R. (2006), Innovation Systems and Institutional Regimes: The Construction of Different Types of National, Sectoral, and Transnational Innovation Systems, in Lorenz, E., Lundvall, B.A. (eds.), How Europe's Economies Learn: Coordinating Competing Models, Oxford University Press, Oxford, pp. 343-380.

*** (2004), Monographs Candidate Countries. Vocational Education and Training and Employment Services in Romania, European Training Foundation, http://www.etf.europa.eu/ pubmgmt.nsf/(getAttachment)/4EACB40E5131E265C12570270057ED59/\$File/ ENL_MON_RO_04_EN.pdf.

*** (2005), Working conditions in the European Union: Work organization, European Foundation for the Improvement of Living and Working Conditions, http:// www.eurofound.europa.eu/pubdocs/2008/68/en/1/ef0868en.pdf

* * * (2009), Accesul tinerilor pe piața forței de muncă, Comunicat de presă nr. 237 din 3 decembrie 2009, Modul ad hoc ataşat cercetării statistice asupra forței de muncă în gospodării (AMIGO) în trimestrul II 2009 - adresat tinerilor în vârstă de 15-34 ani,

http://www.insse.ro/cms/files/statistici/comunicate/alte/CIC_trll09.pdf.

* * * (2009), Educatie de calitate pentru piata muncii, Proiectul Adaptarea activă a educației la cerințele pieței muncii, Program Phare 2006/018-147.05.01, Editura Universitară, Bucharest, http://www.aracis.ro/fileadmin/ARACIS/Proiecte/Anvelopa/ Volum_Educatie_de_Calitate_pentru_Piata_Muncii_VF.pdf 
Irena MOCANU

* * * (2010), Sinteza datelor privind rezultatele obținute la Bursa locurilor de muncă pentr absolvenți din data de 24.09.2010 - evaluare la o lună, Agenția Națională pentru Ocuparea Forței de Muncă, www.anofm.ro.

Initial submission, February 5, 2011

Revised submission, June 20, 2011

Final acceptance, November 30, 2011

Correspondence: Institute of Geography, Romanian Academy, 12, Dimitrie Racovita street, Bucharest, Romania.

E-mail: mocanitai@yahoo.com 